\title{
Biosensor-based comparison of the ecotoxicological contamination of the wastewaters of Southern Russia and Southern Germany
}

\author{
I. S. Sazykin ${ }^{1}$ M. A. Sazykina ${ }^{1}$ L. E. Khmelevtsova ${ }^{1}$ - E. A. Mirina ${ }^{1}$ • \\ E. M. Kudeevskaya ${ }^{1}$ - E. A. Rogulin ${ }^{2}$ A. V. Rakin ${ }^{2}$
}

Received: 2 August 2015/Revised: 17 November 2015/Accepted: 6 January 2016/Published online: 25 January 2016

(C) Islamic Azad University (IAU) 2016

\begin{abstract}
To assess the ecotoxicological and sanitary situation in two European metropolis, Rostov-on-Don (Southern Russia) and Munich (Southern Germany), wastewaters of the two cities were examined with a panel of bacterial lux-biosensors: Vibrio aquamarinus VKPM B-11245, Escherichia coli MG1655 (pXen7), E. coli MG1655 (pRecA-lux), E. coli MG1655 (pSoxS-lux), E. coli MG1655 (pKatG-lux), E. coli MG1655 (pIbpAlux), E. coli MG1655 (GrpE-lux), E. coli MG1655 (pFabAlux). The presence of different genotoxic compounds and substances with the oxidative and membrane-damaging effects was revealed in contaminated wastewater with the applied panel of the lux-biosensors. The integral toxicity was approximately the same in both cities but demonstrated opposite trends. The presence of genotoxicants and peroxides was higher in the majority of the Munich wastewater samples. There were also differences in the presence of individual toxicants. The presence of the genotoxic compounds might also promote development and dissemination of several antibiotic resistance traits found in microorganisms, a feature more pronounced in Rostov-on-Don wastewaters. By means of polymerase chain reaction assay, antibiotic resistance genes to such antibiotics as ermB, vim and $v a n B$ were revealed in two Munich samples. Antibiotic resistance genes were present at all Rostov samples, and genes $n d m$, vanA, vanB and
\end{abstract}

M. A. Sazykina

submarinas@list.ru

1 Academy of Biology and Biotechnology Named After D.I. Ivanovsky, Southern Federal University, Stachki, 194/1, Rostov-on-Don, Russia 344090

2 Max von Pettenkofer-Institut, Pettenkofer str. 9a, 80336 Munich, Germany
ermB were found. Taken together, the proposed analytical approach with the application of the constructed panel of biosensors can be applied for monitoring of the ecotoxicological contamination in the wastewaters of large cities.

Keywords Antibiotic resistance genes - Cell membrane damage $\cdot$ Genotoxicity $\cdot$ Municipal sewage $\cdot$ Prooxidant effect

\section{Introduction}

Industry development, growth of the cities and population lead to increase in both water consumption and water disposal (Figueras and Borrego 2010). Influx of a large amount of poorly purified sewage deteriorates the ecological and epidemiological quality of water ecosystems (Poma et al. 2012).

Effluents from sewage treatment plants are sources of a wide range of chemicals entering the aquatic environment (Sturve et al. 2008). As a result of industrial activity and household usage, a mixture of chemicals including PAHs, solvents, heavy metals, plasticisers, pharmaceuticals, flame retardants, antioxidants and washing and cleaning-related compounds is dumped into sewage (Paxéus 1996; HallingSorensen et al. 1998).

The high number of pollutants in sewage (Stadler et al. 2012; Tang et al. 2013) leads to the need for ecotoxicological assessment of water quality. Fast and effective methods are necessary for toxicity assessment. They include evaluation of such toxicity parameters as integral toxicity, genotoxicity and oxidative stress. As a rule, their detection is quite complicated to perform as a big amount of substances can cause similar effects (Tang et al. 2013). The chemical analysis that initially prevails in toxicity 
assessment of sewage, determines components and concentration of the polluting substances in the environment. However, it is unable to reveal the mechanisms of their toxic effects and the impact of pollution on living organisms (Ma et al. 2014).

One of the most promising approaches used for the environment monitoring is the application of biosensors (Daniel et al. 2008; Palchetti and Mascini 2008; Sorensen et al. 2006), including those based on bioluminescent bacteria (Ren 2004; Woutersen et al. 2011; Elad et al. 2011, 2013; Ji et al. 2013; Zhang et al. 2013; Ding et al. 2015; Eltzov et al. 2015).

Usage of lux-biosensor batteries provides an opportunity to evaluate the presence of different toxic substances in ecosystems simultaneously: DNA-tropic compounds (Ptitsyn et al. 1997; Vollmer et al. 1997; Biran et al. 2010), heavy metals (Lyngberg et al. 1999; Hakkila et al. 2004; Ivask et al. 2009), polychlorinated biphenyls (Layton et al. 1998), substances causing oxidative stress (Lee and $\mathrm{Gu}$ 2003, Zavilgelsky et al. 2007), damaging proteins (Van Dyk et al. 1994, 1995) and membranes (Choi and Gu 1999), etc. Besides, there is an opportunity to make a preliminary conclusion about the mechanism of their action.

The ability of many compounds to damage the genetic material of living organisms deserves special attention. The presence of the genotoxicants might significantly increase mutation rates and support rapid development and dissemination of such unwanted features as antibiotic resistance genes (ARG) number increase in microorganisms (Harwood et al. 2001; Iversen et al. 2002; Schwartz et al. 2003; Sahlström et al. 2009; Munir et al. 2011; Korzeniewska and Harnisz 2013; Amos et al. 2014).

Polymerase chain reaction (PCR) of the total DNA extracted from sewage or active sludge from waste treatment facilities can be successfully applied to follow the presence of ARG (Guillaume et al. 2000; Szczepanowski et al. 2009). It is known that traditional methods of sewage treatment are not effective enough and both effluents and active sludge of sewage treatment plants contain ARG and antibiotic resistant bacteria in significant amounts (Munir et al. 2011).

Accordingly, combining toxicity testing by means of bacterial biosensors and investigating ARG presence in sewage will allow obtaining a complex assessment of biological safety and quality of the municipal sewage.

The approach proves to be helpful in comparison with sewages of two large cities of Western and Eastern Europe and supplies with information on ecotoxicological parameters and presence of several determinants of resistance and bacterial contamination of their wastewaters. Wastewaters of the Rostov-on-Don and Munich were selected as the subject of the study. Studied wastewaters were collected at wastewater treatment plants of the Rostov-on-Don and Munich during the years 2012-2013. Munich and Rostovon-Don are similar according to the number of inhabitants ( $\sim 1,300,000$ and $\sim 1,100,000$ people), but considerably differ from the viewpoint of the living standards and of the population mobility.

\section{Materials and methods}

The present research was carried out on wastewaters.

\section{Site of collection}

The studied wastewaters were collected at municipal wastewater treatment plants of the Rostov-on-Don and Munich.

\section{Sampling}

Wastewater samples were taken at wastewater treatment plants, at the stage of microbiological purification on October 05, 2012; December 03, 2012; May 29, 2013; and July 08, 2013. A portion $(500 \mathrm{ml})$ of each sample was packed in sterile chemically clear containers and sent to the laboratory. In the laboratory, it was subsampled into $50 \mathrm{ml}$ aliquots and stored at $-20{ }^{\circ} \mathrm{C}$ until analyzed.

\section{Bacterial strains and culture conditions}

Strains Vibrio aquamarinus VKPM B-11245 (Vibrio aquamarinus DSM 26054), E. coli MG1655 (pXen7-lux), E. coli MG1655 (pRecA-lux), E. coli MG1655 (pKatGlux), E. coli MG1655 (pSoxS-lux), E. coli MG1655 (pIbpA-lux), E. coli MG1655 (pFabA-lux) were used in this study. Strains are kindly provided by I.V. Manukhov (Federal State Unitary Enterprise "GosNIIGenetika").

Strain Vibrio aquamarinus VKPM B-11245 was isolated by us from Black Sea water. It has high sensitivity for toxicants and used for analysis of general toxicity (Sazykin et al. 2014). The strain is more sensitive compared to the recombinant Escherichia coli strain with the cloned lux-operon $P$. leiognathi, used in the test system «Ecolum » (Methods 2007; Deriabin and Aleshina 2008).

The biosensor with PrecA promotor fixes the presence of the factors causing damage of DNA in a cell. The biosensor with the PkatG promoter fixes production of hydroperoxides in a cell and with the PsoxS promotorsuperoxide anion and NO (Vollmer et al. 1997; Belkin et al. 2003; Lee and Gu 2003; Zavilgelsky et al. 2007; Lushchak 2011). Biosensor strain with PibpA promotor responds to the substances damaging proteins (Van Dyk et al. 1994, 1995). Biosensor strain with PfabA promotor 
responds to the substances damaging membranes (Choi and Gu 1999).

Bioluminescent strains were obtained by transformation of $E$. coli MG1655 by hybrid plasmids pXen7, pRecA-lux, pKatG-lux, pSoxS-lux, pIbpA-lux, pFabA-lux. The gene cassette luxCDABE Photorhabdus luminescens under the control of Plac, PrecA, PkatG, PsoxS, PibpA, PfabA promoters, respectively, was used in these biosensors. These plasmids are created on the basis of pBR322 and contain a selective marker of ampicillin resistance (Amp gene).

The bacterial strains were cultivated in Luria-Bertani (LB) medium (Maniatis et al. 1982), containing $100 \mu \mathrm{g}$ of ampicillin/ml. The cultures were grown under constant shaking to early exponential phase at $37^{\circ} \mathrm{C}$. Cells were used immediately for stress induction tests.

\section{Chemicals}

All of the chemicals used were of analytical grade. Hydrogen peroxide was from "Ferraine." Methyl viologen, $N$-methyl$N$-nitro- $N$-nitrosoguanidine (MNNG) ("Sigma-Aldrich") and $\mathrm{ZnSO}_{4}$ were obtained from «Sigma-Aldrich». Pentachlorophenol, glucose-6-phosphate, NADP were obtained from "AppliChem." Test solutions were prepared in distilled water immediately before the tests. Rat liver microsomal enzymes (S9 fraction) were from "Moltox."

\section{Biosensors assay procedure}

Wastewater samples to be tested were added in $20-\mu 1$ portions to wells of a 96-well microplate containing $180 \mu \mathrm{l}$ of the culture. In the control, $20 \mu \mathrm{l}$ of distilled water was added. Twenty microliters of toxicant solution (in case of positive control for promoter activation) was introduced into other wells.

For control activation of the PsoxS promoter, methyl viologen was used, for PkatG promoter activation-hydrogen peroxide, for $\operatorname{Prec} A$ promoter activation- $N$ methyl- $N^{\prime}$-nitro- $N$-nitrosoguanidine $(\mathrm{MNNG})$ (« Sigma »), for PIbpA promoters-high temperature $\left(50{ }^{\circ} \mathrm{C}, 5 \mathrm{~min}\right)$, for PfabA promoter-pentachlorophenol. As positive control for E. coli MG1655 (pXen7), zinc sulfate was used.

When determining genotoxicity in an embodiment with metabolic activation (designated in the tables as "+S9"), $160 \mu \mathrm{l}$ of culture, $20 \mu \mathrm{l}$ of the water sample (in the control variant $-20 \mu \mathrm{l}$ of distilled water) and $20 \mu \mathrm{l}$ of activating mixture comprising $\mathrm{S} 9$ fraction of rat liver microsomal enzymes ("Moltox," USA) were added to the wells.

Luminescence measurements were taken on microplate luminometer LM-01T ("Immunotech"). Numerical values of a bioluminescence were expressed in relative luminescence units.

\section{Calculation}

The criterion of toxic influence is bioluminescence intensity change of the test object in the researched sample in comparison with the control sample.

Strong toxic influence of the studied toxicant on bacteria is evaluated according to the inhibition of their bioluminescence for 30-min exposition period.

The quantitative assessment of the test reaction parameter is reflected as a dimensionless number-the toxicity index $(\mathrm{T})$, calculated according to the formula:

$T=100\left(I_{\mathrm{k}}-I_{\mathrm{c}}\right) / I_{\mathrm{c}}$,

where $I_{\mathrm{c}}$ and $I_{\mathrm{k}}$ are the intensity of bacteria luminescence in proof and control samples, respectively, at fixed exposition time of the studied solution with test object.

In some cases, a situation is possible when bioluminescence intensity of an analyzed sample is higher than that of the control sample. In that case irrespective of the size of negative $T$ value, the conclusion about the absence of the sample toxicity is drawn, and the toxicity index equals zero.

The technique allows three threshold levels of the toxicity index:

- Admissible degree of toxicity: The toxicity index is less than 20 .

- The sample is toxic: The toxicity index is equal or more than 20 and $<50$.

- The sample is highly toxic: The toxicity index is equal or more than 50 .

All the experiments were carried out in three independent replications.

The induction factor, $F_{\mathrm{i}}$, was defined as the relation of luminescence intensity of a lux-biosensor suspension, containing tested sample $\left(L_{\mathrm{c}}\right)$, to the luminescence intensity of a lux-biosensor control suspension $\left(L_{\mathrm{k}}\right): F_{\mathrm{i}}=L_{\mathrm{c}} / L_{\mathrm{k}}$. When the degree of luminescence induction is evaluated in environmental samples, it should be noted that many of the substances included in their composition, can enhance and suppress bacterial bioluminescence, influencing the bacterial luciferase enzyme that can cause artifacts. To solve this problem, the isogenic E. coli MG1655 (pXen7) lux-operon is under the control of a constitutive promoter which was used to correct the artifacts associated with changes in luciferase activity.

Therefore, besides, the induction factor coefficient of luminescence suppression $(K)$ was determined: $K=l_{\mathrm{c}} / l_{\mathrm{k}}$, where $l_{\mathrm{c}}$-luminescence intensity suspension lux-strain with constitutive promoter in the presence of the test compound; $l_{\mathrm{k}}$-luminescence intensity control suspension lux-strain with constitutive promoter. 
The correct values of the induction factor were calculated using the formula $I=F_{\mathrm{i}} / K$, where $F_{\mathrm{i}}$-induction factor, $K$-coefficient of luminescence suppression.

Difference reliability of bioluminescence in experiment from control value was estimated by $\mathrm{t}$-criterion with the help of Excel program. The conclusion about sample toxicity was made at $p<0.05$.

If at significant differences from control induction factor values were $<2$, the detected genotoxic effect was evaluated as «weak», and if they were in the range from 2 to 10 - as «medium», above 10-as «strong». All the experiments were carried out three times independently.

\section{DNA extraction from samples of sewage}

Forty milliliters of each sewage sample was centrifuged for 7 min at $8000 \mathrm{~g}, 4{ }^{\circ} \mathrm{C}$ (Allegra X-30R centrifuge, Beckman Coulter, USA), and the sediment was suspended in $800 \mu \mathrm{l}$ of TE buffer (10 mM Tris, $1 \mathrm{mM}$ EDTA, $\mathrm{pH}$ 8.0) and transferred into 2-ml Eppendorf tubes. Then, $200 \mu \mathrm{l} 10 \%$ of SDS was added to resuspend the sediment and carefully mixed. The suspension was incubated for $30 \mathrm{~min}$ at $99{ }^{\circ} \mathrm{C}$, incubated with $250 \mu \mathrm{l}$ of $5 \mathrm{M} \mathrm{NaCl}$ solution and carefully mixed. Then, it was centrifuged for $5 \mathrm{~min}$ at $14000 \mathrm{~g}$, at room temperature (MiniSpin plus centrifuge, Eppendorf, Germany), and the supernatant was transferred to a new 2-ml Eppendorf tubes. To the supernatant, $750 \mu \mathrm{l}$ of the isopropanol was added; the mixture was allowed to dissolve for $10 \mathrm{~min}$ at $+4{ }^{\circ} \mathrm{C}$ and then centrifuged $7 \mathrm{~min}$ at $14,000 \mathrm{~g}$. The sediment was washed twice with $70 \%$ ethanol and dissolved in deionized water.

\section{PCR assay}

Commercial available PCR kits from "Litekh" (Moscow, Russia) were used for PCR assay. Resistance to carbapenems (genes vim, ndm, oxa-48), cephalosporins (genes ctx-M и mecA), glycopeptides-vancomycin and teicoplanin (genes vanA and vanB) and erythromycin (gene ermB) was discovered in sewage samples. Amplification was carried out in 0.2-ml PCR test tubes. In total, $20 \mu \mathrm{l}$ of PCR mix and $5 \mu \mathrm{l}$ of DNA from sewage were introduced into the tubes. PCR assays were carried out according to the protocol of the manufacturer using the T-100 amplifier ("Bio-Rad," USA). Amplification products were detected by horizontal electrophoresis. The presence of a band corresponding in size to inner control included into the PCR mix proved the success of the amplification process. The presence of antibiotic resistance genes was confirmed by the presence of a band corresponding to positive control included into each PCR kit.

Electrophoresis of the obtained amplicons was carried out in $1,2 \%$ agarose gel, in $0,5 \mathrm{X}$ TBE buffer $(0.54 \mathrm{~g} / 1$ Tris base, $0.275 \mathrm{~g} / \mathrm{l}$ boric acid, $1 \mathrm{mM}$ EDTA, $\mathrm{pH} 8.3$ ) for $1 \mathrm{~h}$ at $7 \mathrm{~V} / \mathrm{cm}$ in the SE-2 camera for horizontal electrophoresis ("Helikon," Russia).

\section{Results and discussion}

A battery of bacterial lux-biosensors was applied to assess the toxicity of Rostov-on-Don and Munich wastewaters, and the pollution dynamics within the studied time period was evaluated. The use of a battery of bioluminescent tests can indicate general stress as a result of complex mixtures and provide information about the real risk to water environment.

The data presented allow the comparison of pollutants presence in wastewaters of the two cities (Table 1). Values of the bioluminescence induction factor $\left(F_{\mathrm{i}}\right)$ of bacterial luxbiosensors on the basis of $E$. coli MG1655 were obtained after diluting wastewaters 1: 100 due to the high toxicity of wastewaters, which does not allow to evaluate luminescence induction of bacterial sensor strains adequately (Eltzov et al. 2015). A natural biosensor strain Vibrio aquamarinus demonstrated even higher sensitivity to the integrated toxicity, in comparison with lux-biosensors on the basis of E. coli, and thus, the samples were diluted 1:1000.

According to the data presented in Fig. 1, the maximum integrated toxicity in Rostov-on-Don wastewaters was observed in October 2012 and that of Munich wastewaters-in July 2013. In December 2012, May 2013 and July 2013, the toxicity index decrease was registered in wastewaters of Rostov-on-Don. On the contrary, the toxicity index was higher in the wastewaters of Munich. Thus, during the observation period, the Rostov and Munich wastewaters showed comparable values of integrated toxicity, but, simultaneously, oppositely directed trends.

Luminescent bacteria (Vibrio fischeri, Photobacterium phosphoreum, etc.) have been used for assessing the integral toxicity in ecological monitoring for many years. One of the results of their response is a change in light emission intensity depending on sample toxicity degree. Results from luminescent bacteria acute toxicity test proved to be a valuable tool for efficient wastewaters pollution control (Rodrigues and Umbuzeiro 2011; Kokkali and Delft 2014; Prasse et al. 2015).

For instance, it was shown by Palma et al. (2010) that $V$. fisheri luminescence suppression correlates with the general content of phosphorus, chlorine compounds and heavy metals. $P$. phosphoreum was successfully used for determination of different molecular weight fractions of sludge treating synthetic wastewater containing 4-chlorophenol (Zhao et al. 2015). V. fischeri was used for assessment of ecotoxicity of mobile forms of heavy metals in sewage sludge (Gondek et al. 2014). 
Table 1 Bioluminescent response of bacterial lux-biosensors to Rostov-on-Don and Munich wastewaters

\begin{tabular}{|c|c|c|c|c|c|c|c|}
\hline \multirow{3}{*}{$\begin{array}{l}\text { Date and location } \\
\text { of sampling }\end{array}$} & \multirow{3}{*}{$\begin{array}{l}\text { The toxicity index }(\mathrm{T}) \\
\text { Vibrio aquamarinus } \\
\text { VKPM } \\
\text { B-11245 }\end{array}$} & \multicolumn{6}{|c|}{ The induction factor (I) } \\
\hline & & \multicolumn{2}{|c|}{$\begin{array}{l}\text { E. coli } \\
\text { MG1655 } \\
\text { (pRecA-lux) }\end{array}$} & \multirow[t]{2}{*}{$\begin{array}{l}\text { E. coli } \\
\text { MG1655 } \\
\quad \text { (pKatG-lux) }\end{array}$} & \multirow[t]{2}{*}{$\begin{array}{l}\text { E. coli } \\
\text { MG1655 } \\
\quad(\text { pSoxS-lux) }\end{array}$} & \multirow[t]{2}{*}{$\begin{array}{l}\text { E. coli } \\
\text { MG1655 } \\
\quad \text { (pIbpA-lux) }\end{array}$} & \multirow[t]{2}{*}{$\begin{array}{l}\text { E. coli } \\
\text { MG1655 } \\
\quad(\mathrm{pFabA-lux})\end{array}$} \\
\hline & & $-\mathrm{S} 9$ & $+\mathrm{S} 9$ & & & & \\
\hline \multicolumn{8}{|l|}{ October 05,2012} \\
\hline Rostov-on-Don & $20.83^{*}$ & $1.97 *$ & 1.24 & 1.43 & $2.28 *$ & $2.75 *$ & $3.38 *$ \\
\hline Munich & $2.86^{*}$ & $2.16^{*}$ & 1.32 & $2.57 *$ & 1.36 & $2.98^{*}$ & $3.21 *$ \\
\hline \multicolumn{8}{|l|}{ December 03, 2012} \\
\hline Rostov-on-Don & $14.01 *$ & 1.30 & $1.69 *$ & $2.47 *$ & $2.39 *$ & 1.10 & $2.58 *$ \\
\hline Munich & $7.12 *$ & $2.31 *$ & $1.65^{*}$ & $2.66^{*}$ & $2.10^{*}$ & $1.59^{*}$ & $2.69 *$ \\
\hline \multicolumn{8}{|l|}{ May 29, 2013} \\
\hline Rostov-on-Don & $1.22 *$ & $1.71 *$ & $1.64 *$ & $1.71^{*}$ & 1.21 & $2.13^{*}$ & $2.10 *$ \\
\hline Munich & $8.86^{*}$ & $2.90^{*}$ & $2.86^{*}$ & 1.25 & 1.24 & $1.73 *$ & $3.15^{*}$ \\
\hline \multicolumn{8}{|l|}{ July 08, 2013} \\
\hline Rostov-on-Don & $2.86^{*}$ & $1.64 *$ & $2.36^{*}$ & $1.59 *$ & 1.15 & $2.49 *$ & $2.03 *$ \\
\hline Munich & $19.63 *$ & $2.82 *$ & $2.71 *$ & $2.04 *$ & $2.58 *$ & $1.83 *$ & $4.03 *$ \\
\hline
\end{tabular}

* Differences compared to the control samples are statistically significant, t-criterion, $p<0.05$. Metabolic activation samples are marked $+\mathrm{S} 9$, without activation $-\mathrm{S} 9$

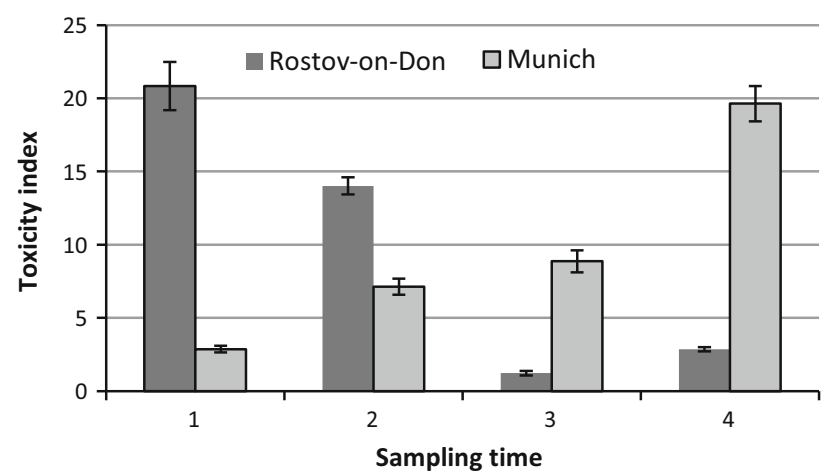

Fig. 1 Integral toxicity of Rostov-on-Don and Munich wastewaters (strain Vibrio aquamarinus VKPM B-11245): 1-October 2012; 2December 2012; 3-May 2013; 4-July 2013

The dump filtrates behave likewise (Bhalla et al. 2013). The concentration of dissolved substances and toxicity of wastewaters increase during the periods of plentiful rainfall and were demonstrated with bacterial lux-biosensors and toxic influence on amphibian larvae (Palma et al. 2010; Park et al. 2014).

June and July are supposed to be the rainiest months in Munich. At the same time, there is an efficient storm drainage system directing wastewaters into the general collectors and further to the wastewater treatment facilities in Munich. In contrast, in Rostov, there is almost no storm drainage and the most part of rainfall flows directly to the Don River. The maximum rainfall in Rostov is in June and from December to January with October being one of the driest months of the year.

Detection of DNA damage is the most essential toxicity effect that can be discovered with the help of bioluminescent bacteria strains. Genotoxicity assessment is of great importance for public and environmental health; therefore, genotoxicity testing is among the most widely used bioassays in ecotoxicology (Prasse et al. 2015).

Escherichia coli MG1655 (pRecA-lux) strain was used for genotoxicity assessment. Comparison of the induction factors determined with the E. coli MG1655 (pRecA-lux) biosensor showed that Munich wastewaters contain a larger amount of direct genotoxicants in winter, spring and summer samples (Fig. 2). During spring and summer, the increase in the induction factor was observed for promutagen substances using metabolic activation (Fig. 3) and direct mutagens (Fig. 2) in Munich wastewaters.

In Rostov wastewaters, on the contrary, the concentration of the direct mutagens and promutagen compounds was the highest in October and in July, correspondingly. One can assume, due to the high levels of pollution in spring and summer in Munich, both direct mutagens and promutagens stream into wastewaters simultaneously, perhaps as part of the same pollutants. The trend toward increase in genotoxicity corresponds with the growth of the integrated wastewaters toxicity in Munich during the observation period. In contrast, in Rostov, there were two maximum genotoxicant inflows separated by an interval of 8 months; one-in October 2012, the inflow of direct genotoxicants, and another-in July 2013-the inflow of 


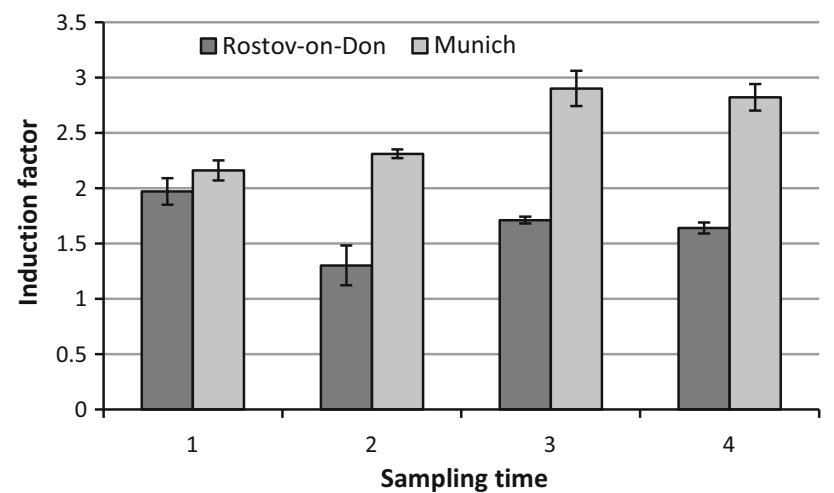

Fig. 2 Wastewaters genotoxicity: E. coli MG1655 (pRecA-lux) biosensor response without using metabolic activation: 1 -October 2012; 2-December 2012; 3-May 2013; 4-July 2013

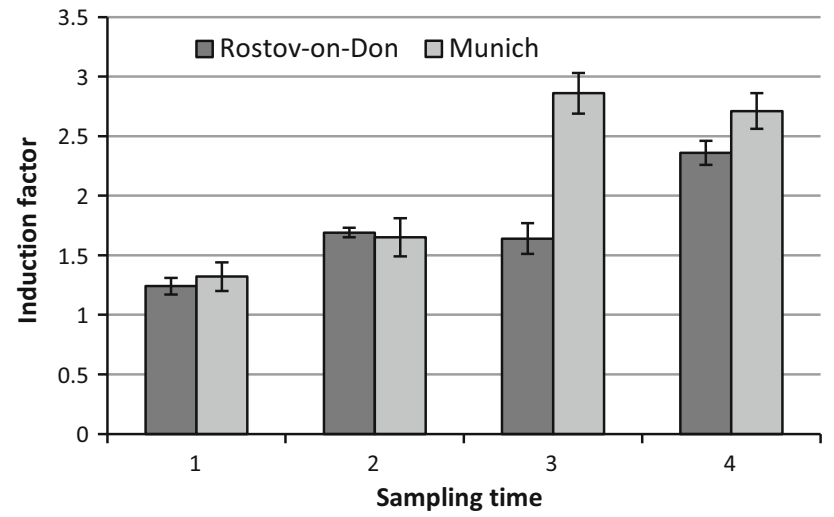

Fig. 3 Wastewaters genotoxicity: E. coli MG1655 (pRecA-lux) biosensor response using metabolic activation: 1-October 2012; 2-December 2012; 3-May 2013; 4-July 2013

promutagens. Moreover, the promutagens increase was linked with the fall of the integrated wastewaters toxicity, potentially indicating changes of the composition of the pollutants.

Many of the wastewater compounds are known to be toxic to organisms due to their ability to form reactive oxygen species and cause oxidative stress (Sturve et al. 2008). Therein, they are also able to cause critical effects such as oxidative damage to lipids and proteins (Livingstone 2001; Carney Almroth et al. 2008). Consequently, using the parameters of oxidative stress in monitoring of environmental pollution has increased in recent years and has a great significance as an early warning signal (Valavanidis et al. 2006).

In order to investigate the presence of compounds that may cause oxidative stress, E. coli MG1655 (pKatG-lux) and E. coli MG 1655 (pSoxS-lux) strains were used. E. coli MG1655 (pIbpA-lux) and E. coli MG1655 (pFabA-lux) sensor strains were used for detection of protein and membrane damages, correspondingly.

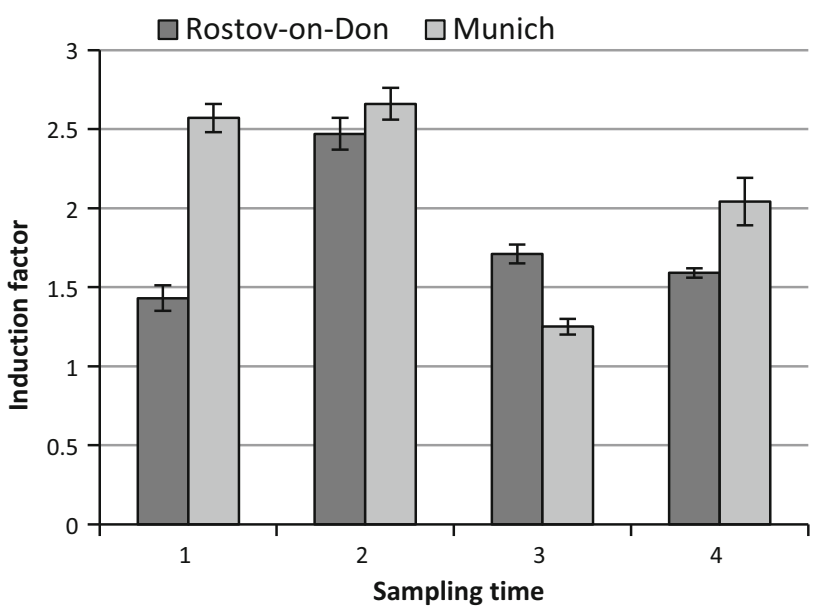

Fig. 4 Wastewaters prooxidant activity: E. coli MG1655 (pKatGlux) biosensor response: 1-October 2012; 2-December 2012; 3May 2013; 4-July 2013

A large amount of peroxides that cause oxidative stress was detected in Munich wastewaters in all time probes except for samples collected in May (Fig. 4). Their maximum concentration both in Munich and in Rostov wastewaters was observed in winter (possibly due to their greater stability at low temperatures and, as a consequence, their accumulation). It should be noted that the contribution of peroxides into integrated Munich wastewaters toxicity during the observation period decreased.

Escherichia coli MG 1655 (pSoxS-lux) biosensor response to the presence of substances that cause the superoxide anion formation was higher in the wastewaters of Rostov-on-Don in October 2012 and in the wastewaters of Munich in July 2013. Their maximum concentration in the wastewaters of Rostov occurred in October and December 2012 and in Munich wastewaters-in July 2013 (Fig. 5). The general trend toward reduction in concentration of substances causing oxidative stress (except October 2012 samples) in Rostov wastewaters correlates with the integrated toxicity decrease.

E. coli MG1655 (pIbpA-lux) sensor strain response to the presence of substances that cause protein damages was the strongest in the wastewaters of Rostov-on-Don and of Munich in autumn (see Fig. 6) and changed likewise over the period of observation in both cities. However, a relative contribution of the substances causing protein damage to the integral toxicity and the number of promutagens increased in Rostov wastewater that indicates qualitative changes in the wastewaters composition. In Munich, on the contrary, the contribution of the protein-damaging agents to the integral toxicity of wastewaters decreased during the whole observation period.

The response of the E. coli MG1655 (pFabA-lux) biosensor to the membrane-damaging substances was 1.5 


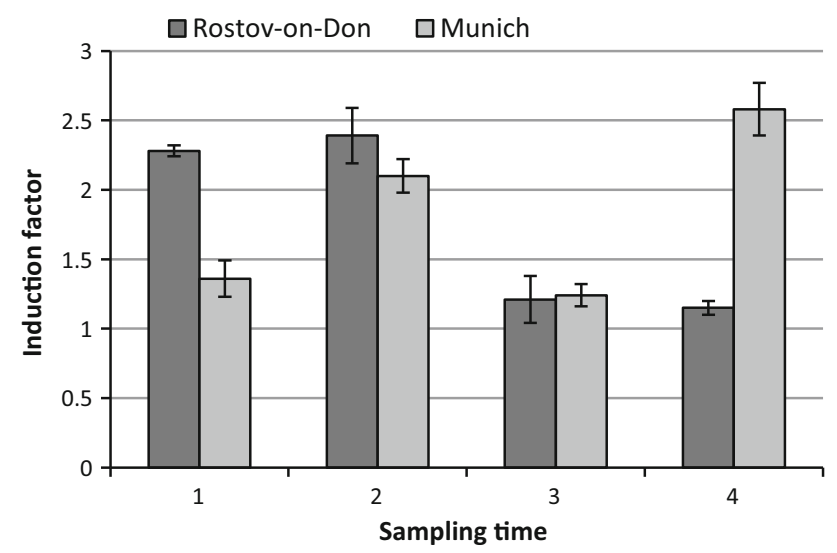

Fig. 5 Wastewaters prooxidant activity: E. coli MG1655 (pSoxSlux) biosensor response: 1-October 2012; 2-December 2012; 3May 2013; 4-July 2013

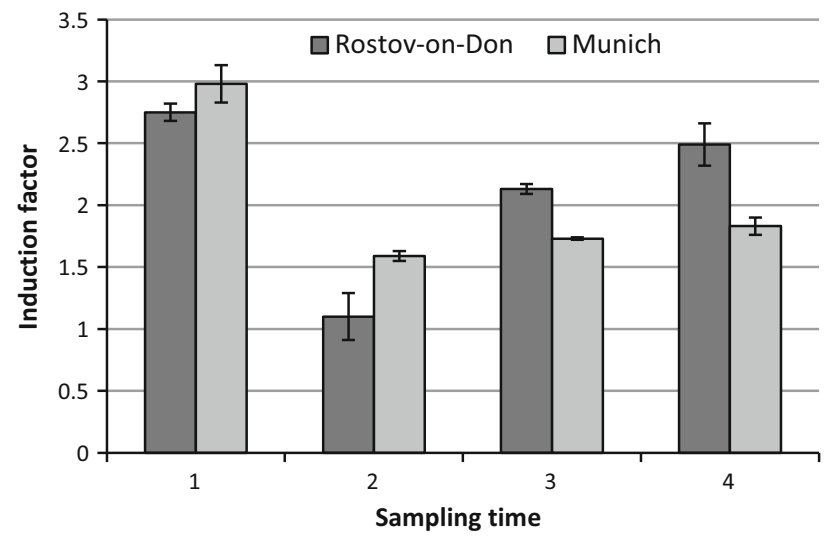

Fig. 6 Detection of protein-damaging substances in wastewaters: E. coli MG1655 (pIbpA-lux) biosensor response: 1-October 2012; 2-December 2012; 3-May 2013; 4-July 2013

and 2 times higher in Munich sewage in May and July 2013. The increase in the membrane-damaging substance concentrations was observed in Munich wastewaters during winter-summer period. Their presence decreased in Rostov wastewaters over the research period (Fig. 7). The changes in concentrations of the membrane-damaging substances (e.g., surfactants) largely correlated with the changes in the integral wastewaters toxicity of Rostov and Munich during the observation period. Thus, it can be assumed that the membrane-damaging agents were mainly responsible for the integral wastewaters toxicity. Genotoxicants of both direct and indirect action were the main toxic pollutants for Munich and substances that caused oxidative stress-for Rostov-on-Don.

The toxicity of Munich wastewaters seems to be primarily caused by the presence of membrane-damaging substances, genotoxicants and substances causing formation of superoxide anion (especially in the summer

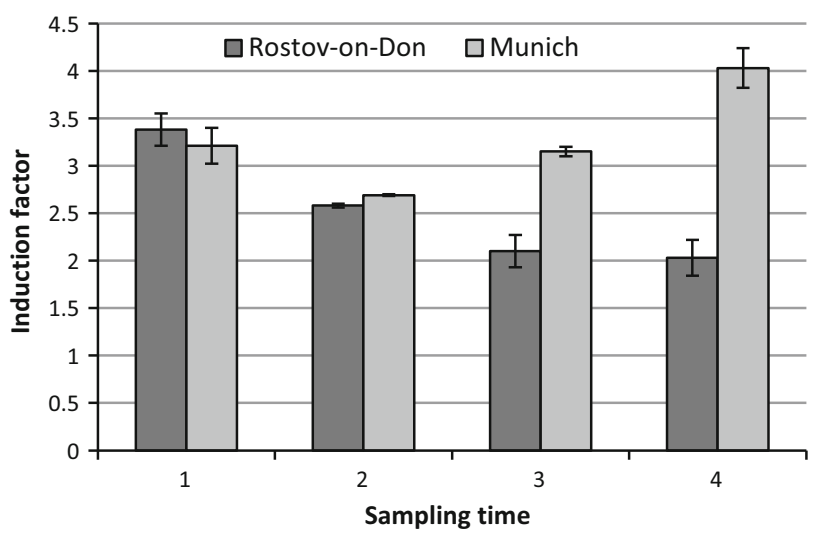

Fig. 7 Detection of membrane-damaging substances in wastewaters: E. coli MG1655 (pFabA-lux) biosensor response: 1-October 2012; 2-December 2012; 3-May 2013; 4-July 2013

sample). This is supported by the highest responses of the biosensors E. coli MG1655 (pFabA-lux), E. coli MG1655 (pRecA-lux) and E. coli MG 1655 (pSoxS-lux) along with the highest index of integrated toxicity of Vibrio aquamarinus VKPM B-11245, respectively. Most probably, the presence of the prooxidant substances can promote genotoxic effects, either by activating promutagens by oxidation or by direct DNA alkylation.

Integral toxicity of Rostov-on-Don wastewaters is also largely conditioned by cell membrane damage. Direct mutagens and substances that cause oxidative stress (primarily superoxide anion) also contribute to the toxicity. Thus, the similar mechanism of toxic action of municipal waste can be stated in these two cities.

PCR analysis of the total DNA isolated from sewage indicated the presence of genes confirming resistance to erythromycin $(\mathrm{ermB})$ in Munich samples dating from December 03, 2012, and July 08, 2013, and the presence of vim genes (Enterobacteriaceae and Pseudomonas resistance to carbapenems) and vanB genes (Enterococcus resistance to teicoplanin) in a sample from December 03, 2012. However, in spring and autumn samples, none of the analyzed genes was identified. All the total DNA samples from wastewaters of Rostov displayed the presence of ARG: October 05, 2012-resistance to carbapenems ( $n d m)$, vancomycin (vanA) and teicoplanin (vanB); December 03, 2012-erythromycin (ermB); May 29, 2013-erythromycin (ermB), carbapenems $(n d m)$, vancomycin (vanA) and teicoplanin (vanB); July 08, 2013-erythromycin (ermB) and teicoplanin (vanB).

Although even in Germany, only one-fourth of antibiotics can be associated with their use in hospitals (Kümmerer and Henninger 2004), the constant presence and a wide range of ARG in the Rostov-on-Don wastewaters, 
compared to Munich, are probably due to the free public availability of antibiotics (OTC sales) and less control of the antibiotics usage in Russia.

ARG in Munich sewage were detected in winter and summer samples, which also caused the largest oxidative stress response in bacterial biosensors (SoxS-lux and KatGlux). In Rostov sewage, on the contrary, the greatest variety of ARG was determined in autumn and spring samples. These samples showed a higher induction factor of the biosensor responding to direct mutagens (RecA-lux without metabolic activation). Both effects, detected with the biosensors, may be caused by biocides. Gaze et al. (2011) reported an increase in the number of mobile genetic elements with resistance genes after bacterial exposure to biocides and detergents. On the other hand, no influence of detergents has been observed; biosensor induction coefficient for membranes damage [E. coli MG1655 (pFabAlux)] did not correlate with the presence of variety of ARG in sewage. Also no connection between the range of ARG and response level of the other biosensors was revealed.

\section{Conclusion}

A composite response of the applied biosensors panel allows not only to assess the presence of toxic substances in wastewaters of the two cities, but also to evaluate the toxic spectrum of pollutants in environmental monitoring of aquatic ecosystems. Taken together, the data obtained with the bacterial lux-biosensors demonstrate that the integral toxicity of wastewaters of both Munich and Rostov during the observation period was at the similar level but demonstrated opposite trends. The complex response of the bioluminescent sensors panel revealed that the toxicity of sewage of both Munich and Rostov-on-Don is mainly caused by the membrane-damaging substances. Direct genotoxicants and promutagens, as well as substances that cause oxidative stress, make a significant contribution to the integral toxicity of sewage. The Rostov wastewaters, according to expression of various toxicity mechanisms in different samples, were more susceptible to variations in their qualitative composition compared to Munich wastewaters.

A larger spectrum of ARG was detected in the wastewaters of Rostov-on-Don in comparison with those of Munich. Prooxidant compounds and direct genotoxicants, as wellknown stressors, can directly increase the frequency of mutagenesis but also facilitate distribution of the mobile ARG-bearing elements already present in this epitope. This might directly influence the resistome of municipal wastewaters. The uncontrolled use of antibiotics and their availability in Russia should be kept in mind. However, the effect of membrane-damaging substances on the variety of ARG in municipal wastewaters was not found.
Acknowledgments This study was funded by the Southern Federal University (Grant No. 213.01-07-2014/12 PChVG). This research was performed with the use of the equipment of Collective Using Center of the Southern Federal University "Biotechnology, Biomedicine and Environmental Monitoring."

\section{Compliance with ethical standards}

Conflict of interest The authors declare that they have no conflict of interest.

\section{References}

Amos GCA, Zhang L, Hawkey PM, Gaze WH, Wellington EM (2014) Functional metagenomic analysis reveals rivers are a reservoir for diverse antibiotic resistance genes. Vet Microbiol 171:441-447

Belkin S (2003) Microbial whole-cell sensing systems of environmental pollutants. Curr Opin Microbiol 6:206-212

Bhalla B, Saini MS, Jha MK (2013) Effect of age and seasonal variations on leachate characteristics of municipal solid waste landfill. Int J Res Eng Technol (IJRET) 2:223-232

Biran A, Yagur-Kroll S, Pedahzur R, Buchinger S, Reifferscheid G, Ben-Yoav H, Shacham-Diamand Y, Belkin S (2010) Bacterial genotoxicity bioreporters. Microb Biotechnol 3:412-427

Carney Almroth B, Albertsson E, Sturve J, Förlin L (2008) Oxidative stress, evident in antioxidant defences and damage products, in rainbow trout caged outside a sewage treatment plant. Ecotoxicol Environ Saf 70(3):370-378. doi:10.1016/j.ecoenv.2008.01.023

Choi S, Gu M (1999) A whole cell bioluminescent biosensor for the detection of membrane-damaging toxicity. Biotechnol Bioprocess Eng 4:59-62

Daniel R, Almog R, Ron A, Belkin S, Diamand YS (2008) Modeling and measurement of a whole-cell bioluminescent biosensor based on a single photon avalanche diode. Biosens Bioelectron 24:888-893

Deriabin DG, Aleshina ES (2008) Biotests for mineral waters with natural and recombinant luminescent microorganisms. Prikl Biokhim Mikrobiol 44:417-421

Ding S, Wu J, Zhang M, Lu H, Mahmood Q, Zheng P (2015) Acute toxicity assessment of ANAMMOX substrates and antibiotics by luminescent bacteria test. Chemosphere 140:174-183. doi:10. 1016/j.chemosphere

Elad T, Belkin S (2013) Broad spectrum detection and "barcoding" of water pollutants by a genome-wide bacterial sensor array. Water Res 47:3782-3790. doi:10.1016/j.watres.2013.04.011

Elad T, Almog R, Yagur-Kroll S, Levkov K, Melamed S, ShachamDiamand Y, Belkin S (2011) Online monitoring of water toxicity by use of bioluminescent reporter bacterial biochips. Environ Sci Technol 45:8536-8544

Eltzov E, Yehuda A, Marks RS (2015) Creation of a new portable biosensor for water toxicity determination. Sens Actuators B Chem 221(31):1044-1054

Figueras M, Borrego JJ (2010) New perspectives in monitoring drinking water microbial quality. Int J Environ Res Public Health 712:4179-4202

Gaze WH, Zhang L, Abdouslam NA, Hawkey PM, Calvo-Bado L, Royle J, Brown H, Davis S, Kay P, Boxall ABA, Wellington EMH (2011) Impacts of anthropogenic activity on the ecology of class 1 integrons and integron-associated genes in the environment. ISME J 5:1253-1261. doi:10.1038/ismej.2011.15

Gondek K, Baran A, Kopeć M (2014) The effect of low-temperature transformation of mixtures of sewage sludge and plant materials on content, leachability and toxicity of heavy metals. Chemosphere 117:33-39. doi:10.1016/j.chemosphere.2014.05.032 
Guillaume G, Verbrugge D, Chasseru-Libotte M-L, Moens W, Collard J (2000) PCR typing of tetracycline resistance determinants (Tet A-E) in Salmonella enterica serotype Hadar and in the microbial community of activated sludges from hospital and urban wastewater treatment facilities in Belgium. FEMS Microbiol Ecol 32:77-85

Hakkila K, Green T, Leskinen P, Ivask A, Marks R, Virta MJ (2004) Detection of bioavailable heavy metals in EILATox-Oregon samples using whole-cell luminescent bacterial sensors in suspension or immobilized onto fibre-optic tips. Appl Toxicol 24:333-342

Halling-Sørensen B, Nors Nielsen S, Lanzky PF, Ingerslev F, Holten Lützhøft HC, Jørgensen SE (1998) Occurrence, fate and effects of pharmaceutical substances in the environment-a review. Chemosphere 36(2):357-393

Harwood V, Brownell M, Perusek W, Whitlock JE (2001) Vancomycin-resistant Enterococcus spp. isolated from wastewater and chicken faeces in the United States. Appl Environ Microbiol 67:4930-4933. doi:10.1128/AEM.67.10.4930-4933.2001

Ivask A, Rolova T, Kahru A (2009) A suite of recombinant luminescent bacterial strains for the quantification of bioavailable heavy metals and toxicity testing. BMC Biotechnol 9:41. doi:10.1186/1472-6750-9-41

Iversen A, Kühn I, Franklin A, Möllby R (2002) High prevalence of vancomycin-resistant enterococci in Swedish sewage. Appl Environ Microbiol 68:2838-2842

Ji JY, Xing YJ, Ma ZT, Cai J, Zheng P, Lu HF (2013) Toxicity assessment of anaerobic digestion intermediates and antibiotics in pharmaceutical wastewater by luminescent bacterium. J Hazard Mater 246-247:319-323. doi:10.1016/j.jhazmat.2012.12.025

Kokkali V, Delft W (2014) Overview of commercially available bioassays for assessing chemical toxicity in aqueous samples. Trends Analyt Chem 61:133-155

Korzeniewska E, Harnisz M (2013) Extended-spectrum beta-lactamase (ESBL)-positive Enterobacteriaceae in municipal sewage and their emission to the environment. J Environ Manag 128:904-911. doi:10.1016/j.jenvman.2013.06.051

Kümmerer K, Henninger A (2004) Promoting resistance by the emission of antibiotics from hospitals and households into effluents. Clin Microbiol Infect 9:1203-1214. doi:10.1111/j. 1469-0691.2003.00739.x

Layton AC, Muccini M, Ghosh MM, Sayler GS (1998) Construction of a bioluminescent reporter strain to detect polychlorinated biphenyls. Appl Environ Microbiol 64(12):5023-5026

Lee HJ, Gu MB (2003) Construction of a sodA:luxCDABE fusion Escherichia coli: comparison with a katG fusion strain through their responses to oxidative stresses. Appl Microbiol Biotechnol 60:577-580

Livingstone DR (2001) Contaminant-stimulated reactive oxygen species production and oxidative damage in aquatic organisms. Mar Pollut Bull 42:656-666

Lushchak VI (2011) Adaptive response to oxidative stress: bacteria, fungi, plants and animals. Comp Biochem Physiol C Toxicol Pharmacol 153:175-190

Lyngberg OK, Stemke DJ, Schottel JL, Flickinger MC (1999) A single-use luciferase-based mercury biosensor using Escherichia coli HB101 immobilized in a latex copolymer film. J Ind Microbiol Biotechnol 23:668-676

Ma XY, Wang XC, Ngo HH, Guo W, Wu MN, Wang N (2014) Bioassay based luminescent bacteria: interferences, improvements, and applications. Sci Total Environ 468-469:1-11. doi:10.1016/j.scitotenv.2013.08.028

Maniatis T, Fritsch EF, Sambrook J (1982) Molecular cloning: a laboratory manual. Cold Spring Harbor Laboratory, New York

Methods of Rapid Determination of Integrated Chemical Toxicity of Drinking Water, Surface Water, Groundwater, Wastewater and Treated Wastewater Using Bacterial Test "Ecolum": Guidelines
(Metodika ekspressnogo opredeleniya integral'noy khimicheskoy toksichnosti pit'evykh, poverkhnostnykh, gruntovykh, stochnykh i ochishchennykh stochnykh vod s pomoshch'yu bakterial'nogo testa "Ekolyum": Metodicheskie rekomendatsii). (2007) Moscow

Munir M, Wong K, Xagoraraki I (2011) Release of antibiotic resistant bacteria and genes in the effluent and biosolids of five wastewater utilities in Michigan. Water Res 45:681-693. doi:10.1016/j.watres.2010.08.033

Palchetti I, Mascini M (2008) Nucleic acid biosensors for environmental pollution monitoring. Analyst 133:846-854. doi:10.1039/ b802920m

Palma P, Alvarenga P, Palma V, Matos C, Fernandes RM, Soares A, Barbosa IR (2010) Evaluation of surface water quality using an ecotoxicological approach: a case study of the Alqueva Reservoir (Portugal). Environ Sci Pollut Res Int 17:703-716. doi:10. 1007/s11356-009-0143-3

Park CJ, Ahn HM, Cho SC, Kim TH, Oh JM, Ahn HK, Chun SH, Gye MC (2014) Developmental toxicity of treated municipal wastewater effluent on Bombina orientalis (Amphibia: Anura) embryos. Environ Toxicol Chem 33:954-961. doi:10.1002/etc.2519

Paxéus N (1996) Paper Organic pollutants in the effluents of large wastewater treatment plants in Sweden. Water Res 30(5):1115-1122

Poma HR, Gutiérrez D, Garcé B, Gonzo EE, Rajal VB (2012) Towards a rational strategy for monitoring of microbiological quality of ambient waters. Sci Total Environ 433:98-109

Prasse C, Stalter D, Schulte-Oehlmann U, Oehlmann J, Ternes TA (2015) Spoilt for choice: a critical review on the chemical and biological assessment of current wastewater treatment technologies. Water Res 87:237-270. doi:10.1016/j.watres.2015.09.023

Ptitsyn LR, Horneck G, Komova O, Kozubec S, Krasavin EA, Bonev M, Rettberg PA (1997) biosensor for environmental genotoxin screening based on an SOS lux assay in recombinant Escherichia coli cells. Appl Environ Microbiol 63:4377-4384

Ren S (2004) Assessing wastewater toxicity to activated sludge: recent research and developments. Environ Int 30(8):1151-1164

Rodrigues ES, Umbuzeiro Gde A (2011) Integrating toxicity testing in the wastewater management of chemical storage terminals-a proposal based on a ten-year study. J Hazard Mater 186(2-3):1909-1915. doi:10.1016/j.jhazmat.2010.12.083

Sahlström L, Rehbinder V, Albihn A, Aspan A, Bengtsson B (2009) Vancomycin resistant enterococci (VRE) in Swedish sewage sludge. Acta Vet Scand 51:24. doi:10.1186/1751-0147-51-24

Sazykin IS, Sazykina MA, Kudeevskaya EM, Sazykina MI (2014) The strain Vibrio aquamarinus, a method for determining the toxicity of samples with it and test culture to determine the toxicity of samples. Russian Federation Patent number 2534819. IPC C12N1 / 20 C12R1 / 63, C12Q1 / 02. Bulletin 34

Schwartz T, Kohnen T, Jansen B, Obst U (2003) Detection of antibiotic-resistant bacteria and their resistance genes in wastewater, surface water, and drinking water biofilms. FEMS Microbiol Ecol 43:325-335. doi:10.1111/j.1574-6941.2003.tb01073.x

Sorensen SJ, Burmolle M, Hansen LH (2006) Making bio-sense of toxicity: new developments in whole-cell biosensors. Curr Opin Biotechnol 17:11-16

Stadler LB, Ernstoff AS, Aga DS, Love NG (2012) Micropollutant fate in wastewater treatment: redefining "removal". Environ Sci Technol 46(19):10485-10486

Sturve J, Almroth BC, Förlin L (2008) Oxidative stress in rainbow trout (Oncorhynchus mykiss) exposed to sewage treatment plant effluent. Ecotoxicol Environ Saf 70(3):446-452. doi:10.1016/j. ecoenv.2007.12.004

Szczepanowski R, Linke B, Krahn I, Gartemann KH, Gützkow T, Eichler W, Pühler A, Schlüter A (2009) Detection of 140 clinically relevant antibiotic-resistance genes in the plasmid metagenome of wastewater treatment plant bacteria showing reduced susceptibility to selected antibiotics. Microbiology 155:2306-2319 
Tang JYM, McCarty S, Glenn E, Neale PA, Warne MSJ, Escher BI (2013) Mixture effects of organic micropollutants present in water: towards the development of effect-based water quality trigger values for baseline toxicity. Water Res 47(10):3300-3314

Valavanidis A, Vlahogianni T, Dassenakis M, Scoullos M (2006) Molecular biomarkers of oxidative stress in aquatic organisms in relation to toxic environmental pollutants. Ecotoxicol Environ Saf 64:178-189

Van Dyk TK, Majarian WR, Konstantinov KB, Young RM, Dhurjati PS, Larossa RA (1994) Rapid and sensitive pollutant detection by induction of heat shock gene-bioluminescence gene fusions. Appl Environ Microbiol 60:1414-1420

Van Dyk TK, Reed TT, Vollmer AC, LaRossa RA (1995) Synergistic induction of the heat shock response in Escherichia coli by simultaneous treatment with chemical inducers. J Bacteriol 177:6001-6004

Vollmer AC, Belkin S, Smulski DR, VanDyk TK, LaRossa RA (1997) Detection of DNA damage by use of Escherichia coli carrying recA':lux, uvrA':lux, or alkA':lux reporter plasmids. Appl Environ Microbiol 63:2566-2571

Woutersen M, Belkin S, Brouwer B, van Wezel AP, Heringa MB (2011) Are luminescent bacteria suitable for online detection and monitoring of toxic compounds in drinking water and its sources? Anal Bioanal Chem 400:915-929. doi:10.1007/s00216-010-4372-6

Zavilgelsky GB, Kotova VYu, Manukhov IV (2007) Action of 1,1dimethylhydrazine on bacterial cells is determined by hydrogen peroxide. Mutat Res 634:172-176

Zhang D, Ding A, Cui S, Hu C, Thornton SF, Dou J, Sun Y, Huang WE (2013) Whole cell bioreporter application for rapid detection and evaluation of crude oil spill in sea water caused by Dalian oil tank explosion. Water Res 47:1191-1200

Zhao J, Chen X, Zhao J, Lin F, Bao Z, He Y, Wang L, Shi Z (2015) Toxicity in different molecular-weight fractions of sludge treating synthetic wastewater containing 4-chlorophenol. Int Biodeterior Biodegrad 104:251-257 